Tér és Társadalom 20. évf. 2006/3. 95-108. p.

Tér és Társadalom

XX. évf. 2006 - 3: 95-108

\title{
KITEKINTÖ
}

\section{HELYI GAZDASÁGFEJLESZTÉS KÖZÉP-KELET-EURÓPÁBAN}

\author{
(Local Economic Development \\ in the Central and Eastern European Countries)
}

\section{MEZEI CECÍLIA}

Kulcsszavak:

helyi gazdaságfejlesztés gazdaságf‘jlesztési eszközök helyi önkornányzatok Közép-Kelet-Európa

Tanulmányunkban a közép-kelet-európai országok helyi gazdaságfejlesztési gyakorlatával, azon beliil is a lehetséges szereplökkel, az alkalmazott eszközrendszerrel és a siker foltételét képezö finanszírozással foglalkozunk. Az elemzés során az egyes országok sajátosságait ügy guäitjuk össze, hogy az igy kapott metszetck egynással összehasonlithatóak legyenek, ezzel segítve a térség közös jellemzöinek neghatározásait.

\section{Bevezetés}

A helyi gazdaságfejlesztés fogalmát sokan, sokféle értelemben használják (Wong 1996). A nemzetközi szakirodalomban a mai napig tisztázatlan a kifejezés tényleges tartalma, jelentése (Bennett-Krebs 1991; Čapková 2005). Elsỏ lépésként ezért definiálnunk kell vizsgálatunk tárgyát.

Saját értelmezésünk szerint a helyi gazdaságfejlesztés olyan, a helyi gazdaság életébe történö, külsö és/vagy belsö eröforrásokat hasznositó, tudatos beavatkozás, melynek kezdeményezöje lehet kiilsö szereplö is (pl. kormányzat, EU, külföldi tőke), de a folyamat kulcsa mégis a helyi szereplök részvétele, akik vagy kezdeményezóként vagy a külsö fejlesztési elképzelés elfogadóiként, támogatóiként és alakitóiként lépnek fel.

Nézetünk szerint a piaci folyamatokba csak közösségi felhatalmazás alapján lehet beavatkozni (Faragó 1990; Bennett-Krebs 1991; Blakely-Bradshaw 2002), így a helyi önkormányzatokat gyakorlatilag kihagyhatatlannak tartjuk a helyi gazdaságfejlesztésböl, de más közremüködők részvétele is sikerfeltétel.

Ebbỏl kifolyólag elemzésünk során a helyi gazdaságfejlesztési szereplöket térképezzük fel néhány közép-kelet-európai ország vonatkozásában. Vizsgáljuk továbbá a helyi gazdaság fejlödését támogató eszközrendszert, illetve az eszközhasználat korlátait kijelölỏ szabályozást és finanszírozási hátteret. 


\section{A helyi gazdaságfejlesztés szereplöi}

A helyi gazdaságfejlesztés folyamatának befolyásolói közül elsöként olyan országok feletti szervezeteket kell kiemelnünk, mint az EU vagy az $\mathrm{OECD}$, amelyek kulcsszerepet töltenek be a partnerségre épülö helyi gazdaságfejlesztés „elterjesztésében”, például ajánlások megfogalmazásával, együttmüködések ösztönzésével vagy speciális helyi gazdaságfejlesztési programok (pl. LEDA; LEED) meghirdetésével (Syrett 1995).

A következő szintet a központi kormányzatok képviselik, hiszen a szabályozási háttér biztosításával, a helyi gazdaságfejlesztési intézményrendszer kiépítésével, a közösségi források garantálásával alapvetỏen meghatározzák a gazdaságfejlesztési törekvések sikerét.

A központosított unitárius országok minclegyikére jellemzö az állam túlsúlya a helyi gazdaságfejlesztési feladat ellátása során. A kormányok, az ágazati minisztériumok és dekoncentrált szerveik föként a források elosztása és a fejlesztési irányok kijelölése révén játszanak domináns szerepet.

\section{A helyi gazdaságfejlesztés térségi közremïködöi}

Országonként változó funkció jut a területi (közigazgatási) szintnek. Miközben Nyugat-Európában az 1990-es évektől a terïleti szint egyre meghatározóbb gazdaságfejlesztési közremüködése figyelhető meg, Közép- és Kelet-Európa országai fáziskésésben vannak e tekintetben is (elhúzódó reformfolyamatok, elmaradó decentralizáció).

Nem mindegy azonban, hogy a területi szint mely képviselöje vesz részt a helyi gazdaságfejlesztésben, ahogyan az sem, hogy mindeközben milyen mozgástér marad a helyi közremúködőknek.

A középszint részvételét alapvetöen meghatározza az ország államtípusa, közigazgatási rendszere (1. táblázat), de a szabályozási háttér is fontos tényező (mely szereplőhöz vagy szereplőkhöz telepíti a törvényhozó a gazdaságfejszés feladatát, illetve eszközrendszerét).

A regionalizált országokban a gazdaságfejlesztés meghatározó alakjaivá általában a választott regionális hatóságok váltak. Lengyelországban a régiók mellett a helyi önkormányzatok is címzettjei a helyi gazdaságfejlesztési feladat- és eszközrendszernek. A szabályozás értelmében a területi tervezés mellett a regionális fejlesztés és a gazdaságfejlesztés (a régiók versenyképességének és innovációs képességének fenntartása, promóció és nemzetközi gazdasági kapcsolatok építése) is egyértelmüen a régiók hatáskörébe tartozik (Young-Kaczmarek 2000; Swicuniewicz 2006). Az újonnan alakult régióknak azonban bizonyosan hosszabb idő kell hatáskörük tényleges gyakorlásához, s ez középtávon felértékeli a járások, de még inkább a helyi önkormányzatok (gminák) gazdaságfejlesztésben betöltött szerepét (Dziemianowicz-Herbst 2005). 
Tér és Társadalom, 20. 2006. 3. 95-108. p.

\begin{tabular}{|c|c|c|c|c|}
\hline \multicolumn{5}{|c|}{$\begin{array}{c}\text { 1. TÁBLÁZAT } \\
\text { A nemzetállamok közigazgatási rendszere } \\
\text { (Public Administrational System of Nation-states) }\end{array}$} \\
\hline Államtipus & Ország & $\begin{array}{c}\text { Szubnacionális } \\
\text { közigazgatási } \\
\text { egységek }\end{array}$ & $\begin{array}{l}\text { Települési } \\
\text { önkor- } \\
\text { mányzatok } \\
\text { száma }\end{array}$ & $\begin{array}{l}\text { Egy ön- } \\
\text { kormány- } \\
\text { zatra jutó } \\
\text { népesség }\end{array}$ \\
\hline $\begin{array}{l}\text { Regionalizált } \\
\text { unitárius }\end{array}$ & Lengyelország & $\begin{array}{l}16 \text { vajdaság } \\
315 \text { járás } \\
\text { (powiat) és } 65 \\
\text { járási jogú } \\
\text { város }\end{array}$ & 2489 & 15300 \\
\hline \multirow{3}{*}{$\begin{array}{l}\text { Decentralizált } \\
\text { unitárius }\end{array}$} & Csehország & 14 régió (kraj) & 6249 & 1600 \\
\hline & Szlovákia & $\begin{array}{l}8 \text { régió (kraj) } \\
79 \text { járás (okres) }\end{array}$ & 2891 & 1900 \\
\hline & Lettország & 26 járás (rajon) & 472 & 3500 \\
\hline \multirow{6}{*}{$\begin{array}{l}\text { Központosított } \\
\text { unitárius }\end{array}$} & Bulgária & $\begin{array}{l}6 \text { régió (oblast) } \\
28 \text { körzet }\end{array}$ & 264 & 32000 \\
\hline & Észtország & $\begin{array}{l}15 \text { megye } \\
\text { (maakonnad) }\end{array}$ & 247 & 5500 \\
\hline & Litvánia & $\begin{array}{l}10 \text { megye } \\
\text { (apskritys) }\end{array}$ & 60 & 60000 \\
\hline & Magyarország & 19 megye & 3145 & 3000 \\
\hline & Románia & $\begin{array}{l}42 \text { megye } \\
\text { (judet) }\end{array}$ & 3004 & 7400 \\
\hline & Szlovénia & $\begin{array}{l}58 \text { admin. } \\
\text { egység }\end{array}$ & 210 & 9500 \\
\hline
\end{tabular}

Forrás: Espon (2006, Annex D., 22); Illés (2002, 111-112); Alexandrova (2006, 240); Kudrycka (2004. 9); KSH (2006); Petkevicius-Linartas (2005, 53); Pilat (2004, 290); Pukis (2004, 112); Rechnitzer (2006, 119, 194, 229, 271, 406); Slovenia (2006); valamint Trasberg $(2006,203)$ alapján saját számítás.

A decentralizált unitárius országok közül Csehországban és Szlovákiában a régiók hatáskörébe tartozik a helyi gazdaságfejlesztés szempontjából lényeges területi tervezés funkciója (Józsa 2006), de a helyi önkormányzatok is fontos funkciókkal rendelkeznek.

A centralizált unitárius országok közül hazánkban a közvetlenül választott megyék a terület- és gazdaságfejlesztés erötlen és eszköztelen területi szereplőivé váltak. A megyei önkormányzatokhoz telepített funkciók és a hozzájuk kapcsolódó pénzügyi háttér, valamint a rendelkezésükre álló eszközrendszer jelzik, hogy nem ők a térségi gazdaságfejlesztés kitüntetett alakjai.

Litvániában a választott képviselökkel nem rendelkezö megyék fontos koordináló, tervezö és fejlesztö szerepet töltenek be a helyi gazdaságfejlesztésben. Míg a vidékfejlesztési és regionális fejlesztési programok menedzselése kizárólagosan a megyék feladata, a területhasználat felügyelte, a tervezés, az oktatás, képzés és a 
foglalkoztatás támogatása, illetve az infrastruktúrafejlesztés területén már a helyi önkormányzatok is rendelkeznek bizonyos hatáskörrel (Petkevicius-Linartas 2005).

$\mathrm{Az}$ 1990-es évektöl megfigyelhetö a terïleti szervezeti formák pluralizálódása. Az önkormányzatok, egycélú önkormányzatok és dekoncentrált szervek mellett olyan szervezetek jelentek meg, mint az ügynökségek, a társulások, a bizottságok, a tanácsok stb. (Pálné Kovács 1999).

Speciális köztes (azaz közhatalom és a piaci szektor közötti) aktoroknak számítanak az ún. regionális fejlesztési ügynökségek. Országonként eltérö jellemzőkkel bíró szervezetekröl van szó, ám közös tulajdonságuk, hogy a hierarchikus állami irányításon kívül helyezkednek el, és közpénzekböl finanszírozzák őket (Pálné Kovács 2003).

A közép-kelet-európai országok közül Lengyelországban például nagyon „,népszerủek" az RDA-k, hiszen a helyi önkormányzatok több mint fele részt vesz a regionális ügynökségekkel közös gazdaságfejlesztési együttmüködésben (Young-Kaczmarek 2000). Lettországban az RDA-k készítik el a tervezési-statisztikai régiók fejlesztési koncepcióit. Mindeközben együttmüködnek a helyi önkormányzatokkal és a dekoncentrált szervekkel is (Espon 2006). Romániában a regionális fejlesztési ügynökségek al regionális fejlesztési tanácsoknak alárendelve múködnek. Feladatuk a tanács múködésének támogatása ( $\mathrm{pl}$. a tervezés, a regionális pénzalapok múködtetése terén), illetve segítségnyújtás a potenciális befektetők számára. Szlovéniában viszont az RDA-k a települési érdekek képviselöi regionális, nemzeti és uniós szinten is. Feladatuk a regionális tervezés, a regionális fejlesztési projektek kezdeményezése és továbbítása nyilvános tenderekre, valamint e projektek monitoringja és értékelése (Rechnitzer 2006).

Szlovákiában a regionális fejlesztési ügynökségek a helyi és a regionális önkormányzatok számára képzési intézményekként, módszertani központokként, illetve uniós tanácsadó centrumokként funkcionálnak (Buček 2005).

Bulgáriában a tervezési-statisztikai régiókban müködö ügynökségek koordinálják a Strukturális Alapokból származó forrásokat, illetve közvetítő, kapesolatépítő szerepük van a köz- és a magánszféra között. A Bolgár Regionális Ügynökségek Szövetsége olyan országos szervezet, amely az RDA-k mellett a KKV-kat támogató központokat is felöleli. A szövetség feladata az ügynökségek közötti tapasztalatcsere elösegítése, és a közös érdekérvényesítés lehetöségének biztosítása. Célja továbbá a KKV-k támogatása. Ennek érdekében feladata a kormányzati szervekkel való együttmüködés, a nemzetközi szervezetekkel való kapcsolattartás, a fejlesztési projektek koordinációja, gyakorlati képzések és konferenciák szervezése, illetve piaci információk gyüjtése és továbbítás (Rechnitzer 2006).

Magyarországon a regionális fejlesztési ügynökségek nem csupán a fejlesztési tanács munkaszervezeteiként, hanem aktív, kezdeményező résztvevökként tevékenykednek a területfejlesztés területén. A klasszikus fejlesztési ügynökségekkel ellentétben a hazai regionális fejlesztési ügynökségek rendeltetése azonban nem gazdaságfejlesztési karakterü, sem a szabályozási háttér, sem pedig a saját célmeghatározásuk alapján (Somlyódyné Pfeil 2004). 
Speciális szereplöknek számítanak a térségfejlesztési tanácsok. Bulgáriában a regionális fejlesztési tanácsok kapcsolattartó (kormány, körzetek, helyi önkormányzatok), tanácsadó szervezetként müködnek (Espon 2006). Romániában a regionális fejlesztési tanácsok hatásköre kiterjed a regionális fejlesztési stratégiák és programok elfogadására, a regionális fejlesztési tervek jóváhagyására, és a regionális pénzalap kezelésére (Rechnitzer 2006). Hazánkban a regionális fejlesztési tanácsok döntỏen pénzelosztó szerepet töltenek be. A szabályozás alapján ugyan feladatuk lenne a gazdaságfejlesztési szereplők közötti koordináció megvalósítása is, ám a gyakorlatban ennek nem tudnak eleget tenni. Ez már csak azért is aggályos, mert a törvényhozó lényegében e koordinatív szerepkörrel azonosítja a regionális tanácsok gazdaságfejlesztési funkcióit (Somlyódyné Pfeil 2004). Magyar sajátosság, hogy még egy területi szintre, a megyékre is létrehoztak, szintén pénzelosztó és szintén korlátozott szerepet betöltő fejlesztési tanácsokat.

\section{A helyi gazdaságfejlesztés helyi szereplöi}

A központi szabályozás és a területi közremüködök sokszínủ helyi gazdaságfejlesztési részvételi módja országonként eltérỏ funkcióhoz juttatja a helyi önkormányzatokat, de ilyen vagy olyan feladat mégis jut nekik, vagyis jellemző résztvevői a helyi gazdaságfejlesztési kezdeményezéseknek.

Bennett és Krebs (199I) megállapítja azt is, hogy a helyi önkormányzatok csak a többi közszereplövel és az egyéb, nem kormányzati résztvevőkkel együttmüködve képesek ezt a feladatot ellátni. Többen (Syrett 1997; Pálné Kovács 2004) a helyi gazdaságfejlesztési aktorok együttmüködéseit látják a siker kulcstényezőjének.

A lengyel helyi önkormányzatok például a következö eszközök használatával központi szerepet játszanak a helyi gazdaságfejlesztésben:

- tervezés, a közösségi erőforrások menedzselése;

- infrastruktúrafejlesztés;

- helymarketing és promóció:

- együttmüködés egyéb szervezetekkel;

- külső források szerzése;

- adókedvezmények, -mentességek nyújtása;

- a helyi KKV-k támogatása;

- „egyablakos” (pl. oktatási, tanácsadó) központok és vállalkozási centrumok létrehozása;

- inkubátorházak, technológiai parkok és ipari övezetek alapítása és támogatása;

- helyi és regionális fejlesztési ügynökségek támogatása;

- munkaerő-képzési kezdeményezések ösztönzése (Dziemianowicz-Herbst 2005; Young-Kaczmarek 2000).

Lengyelországban az önkormányzatok túlnyomó többsége részt vesz valamilyen helyi gazdaságfejlesztési együttmủködésben. A kooperációk egyrészről nemzetközi szervezetekkel jönnek létre, illetve olyan programok kapcsán merülnek fel, mint az 
ENSZ nemzetközi fejlesztési programja, vagy az EU Phare programja. Országos szinten partnerek lehetnek a minisztériumok és a kormányhivatalok, a szektorálisan szervezett kamarák, a nemzeti fejlesztési alapok, valamint egyéb országos (pl. munkaadói) szervezetek (Young-Kaczmarek 2000).

A legnépszerübb partnerszervezetek azonban olyan regionális és helyi intézmények, mint a regionális önkormányzatok, a regionális fejlesztési ügynökségek, a kereskedelmi és iparkamarák valamint a településszövetségek és társulások. A helyi közremüködők közül említést érdemelnek még a helyi vállalkozásfejlesztési és gazdaságfejlesztési szervezetek, illetve a nagyobb állami vállalatok és erömüvek. Nem jellemzö viszont, hogy a helyi önkormányzatok formális együttmüködéseket alakítanának ki a helyi magánvállalkozásokkal (Young-Kaczmarek 2000).

Szlovákiában a helyi önkormányzatok egyre bövülö funkciókkal bírnak a helyi gazdaságfejlesztés területén, ld. vagyongazdálkodás, díjszabás, helyi adó politika, a helyi gazdasági aktivitás felügyelete, a helyi infrastruktúra fejlesztése, közszolgáltatások biztosítása, területi tervek és fejlesztési programok elfogadása (Buček 2005).

A széles körben használt helyi gazdaságfejlesztési eszközök a következők:

- KKV-k támogatása (átlátható szabályozási környezet, információszolgáltatás, a nagyobb városokban: innovációs központok, inkubátorházak, tanácsadó és információs centrumok létesítése);

- munkahelyteremtés (foglalkoztatási programokban való részvétel; saját foglalkoztatás; oktatási, képzési, továbbképzési programok; az elérhetőség javítása a tömegközlekedés fejlesztésével);

- marketing és promóció (imázsjavítás, konferenciákon egyéb rendezvényeken való részvétel, információs és marketingkiadványok készítése);

- telekbiztosítás (telekpolitika úgy mint összefüggő területek kialakítása, felvásárlás, fejlesztés, csere; telephely-politika, Id. a telephelyválasztás befolyásolása; telek-, ingatlanregiszter; telek-alapú információs rendszer; fejlesztési területek kijelölése és beillesztése a helyi tervekbe; barnamezös beruházások elökészítése önkormányzati tulajdonszerzéssel);

- ingatlangazdálkodás (kedvezményes ingatlanértékesítés vagy -bérlet; ingatlanértékesítés részletfizetéssel, beruházáshoz kötött kedvezmények);

- infrastruktúrafejlesztés (a müszaki infrastruktúra fejlesztése; beruházásokban való részvétel telek-, illetve épületbiztosítással);

- ipari és technológiai parkok létesítése;

- adó- és díjkedvezmények (adókedvezmény, adómentesség, türelmi idö, befektetéshez kötött türelmi idő, halasztott adófizetés, részletfizetés, adótartozás kiváltása szolgáltatással vagy beruházással);

- helyi vállalkozások és szervezetek támogatása, társfinanszírozása;

- tőketámogatás az újonnan alapított vállalkozások számára;

- kölcsön nyújtása, garanciavállalás;

- helyi vállalkozások előnyben részesítése az önkormányzati szerződésekben;

- külső források szerzése (banki hitelek, állami, nemzetközi támogatások) (Buček 2005). 
A helyi önkormányzatok együttmúködési, partnerség-építési gyakorlata 2000 óta folyamatosan javul (részben a jogi szabályozás változásának köszönhetỏen). Az önkormányzatok információszolgáltatási és közmeghallgatási kötelezettsége a társadalmi részvétel általános előretörését eredményezte (kivéve a tervezés folyamatát) (Buček 2005).

A helyi gazdaságfejlesztési együttmúködések tipikus szereplöi (Buček 2005):

- helyi önkormányzatok, önkormányzati társulások;

- regionális önkormányzatok;

- járási, regionális és speciális ágazati hivatalok;

- munkaügyi hivatalok;

- oktatási, képzési, kutatási intézmények;

- helyi gazdaságfejlesztési közösségi-magán szervezetek (RDA-k, turisztikai információs központok, SARIO-hivatalok [nemzeti befektetés-ösztönzỏ és kereskedelmi ügynökség], tanácsadó, információs és oktatási központok, innovációs centrumok, inkubátorházak, tervezỏ és programozó szervezetek, pl. SAPARD-hivatalok, Regionális Monitoring Bizottságok);

- magánvállalkozások, vállalatok, vállalkozói szervezetek, egyủttmúködések;

- pénzintézetek;

- tervező, tanácsadó, fejlesztő szervezetek;

- harmadik szektorbeli szervezetek;

- helyi (fejlesztési) társaságok;

- euroregionális intézmények.

Bulgáriában az alábbi általánosan használt helyi gazdaságfejlesztési eszközök keruilnek elötérbe a helyi önkormányzatoknál:

- engedélyek kiadása;

- díjszabás; bérleti díjak megállapítása;

- az önkormányzati vagyon értékesítése (Damianova et al. 2005).

A következö eszközöket jóval szúkebb körben alkalmazzák:

- vállalkozói irodák nyitása (információszolgáltatás és ügyintézés), gyorsított kisvállalkozói ügyintézés, kisvállalkozói egyủttmúködések támogatása;

- inkubátorházak, vállalkozói és technológiai központok alapítása;

- infrastruktúrafejlesztés (csak elvétve tapasztalható, mivel ez zömében a területi önkormányzatok és a kormány kompetenciája);

- kezdeményezések pénzügyi támogatása (hitel, garancia, kötvény);

- önkormányzati marketing;

- hatékony közszolgáltatások biztosítása (Damianova et al. 2005).

A bolgár helyi önkormányzatok partnerség-építési eröfeszítéseit gátolja a helyi vállalkozások általános passzivitása (fóként a korrupció, a bonyolult és időigényes hivatali ügyintézés, illetve a magas tranzakciós költségek miatt); a társadalmi rész- 
vétel gyengesége és a harmadik szektor lassú elöretörése. További akadályozó tényezö az önkormányzatok bizalmatlanságá, amely az önkormányzati kezdeményezésú együttmüködések csekély számán is tetten érhetö (Damianova et al. 2005; Roussinova 2004).

Litvániában komoly problémát okoz, hogy a nagyvárosokat leszámítva a helyi önkormányzatoknak nincs megfelelő képzettségü és nyelvismeretü szakembergárdája a helyi gazdaságfejlesztési feladatok menedzseléséhez. Holott a jogszabályok értelmében a helyi önkormányzatok helyi gazdaságfejlesztési szerepvállalása kiterjed:

- a vállalkozásfejlesztésre és a befektetök vonzására (KKV-fejlesztési programok kidolgozása, vâllal kozásalapítás és engedélyezés, tervezés, az önkormányzati vagyon menedzselése);

- a munkaeró képzésére, továbbképzésére, a szakképzésre (fiatalok képzése, közmunka, a hátrányos helyzetủek társadalmi integrációjának támogatása);

- a helyi közlekedési infrastruktúra tervezésére és fejlesztésére; valamint

- a turizmusfejlesztésre (közrend biztosítása, turizmusfejlesztési programok kidolgozása) (Petkevicius-Linartas 2005).

Litvániában a társadalmi részvétel általában a helyi ügyekben - így a helyi gazdaságfejlesztési kezdeményezésekben is - gyenge, eröteljesebb aktivitás csak a nagyobb városokban tapasztalható (Chandler 2006).

Magyarországon a helyi önkormányzatok a következó helyi gazdaságfejlesztési eszközöket alkalmazzák:

- szolgáltatásfejlesztés, a helyi közszolgáltatások vállalkozói igények szerinti alakítása;

- infrastruktúrafejlesztés;

- információszolgáltatás;

- egyszerüsített vállalkozói ügyintézés;

- befektetési kiadványok készítése;

- adócsökkentés, adómentesség biztosítása;

- telephely-biztosítás, telekgazdálkodás;

- ipari parkok kialakítása, iparterületek kijelölése;

- inkubátorházak létrehozatala;

- a K+F támogatása, innovációs centrumok alapítása;

- üzleti tanácsadás;

- a helyi termékek támogatása;

- a kereskedelmi és a marketing tevékenységek támogatása;

- a képzés, továbbképzés elősegítése;

- a kisvállalkozások támogatása;

- saját beruházás (tókebiztosítás);

- hitelszerzés, hitel-, hitelgarancia-nyújtás;

- együttmúködések kialakítása. 
A helyi önkormányzatok gazdaságfejlesztési célú kapcsolatépítése leginkább a többi önkormányzat (többségben projektorientált együttmüködések), a kistérségi társulások, a térségi területfejlesztési tanácsok, illetve a megyei önkormányzatok felé irányul. A települések többségénél a formalizált, rendszeres vállalkozói kapcsolattartás még nem alakult ki (Mezei 2004). A helyi társadalom helyi kezdeményezésekben való szerepvállalása a történelmi hagyományok, a politikai kultúra és az érdekérvényesítés elfogadott mintái okán nem számottevő (Józsa 2006).

Összegezve a közép-kelet-európai országokban a helyi önkormányzatok biztos szereplöi a helyi gazdaságfejlesztési kezdeményezéseknek. A volt szocialista országokban, ahol a liberalizációs, a privatizációs, a globalizációs és a külföldi tőke beáramlási folyamatokkal szinte egyszerre kellett szembenéznie a piaci szereplöknek, kiemelkedỏ pozícióba kerültek a szabályozási hátteret alakító és az intézményrendszerbe beépülő helyi önkormányzatok (Young-Kaczmarek 2000). Rajtuk kívül azonban még sok helyi közremüködő részt vesz a beavatkozásokban. A lehetséges közbenjárók köre országonként változhat. hiszen az függ a településrendszertöl, a közigazgatási rendszertöl és annak finanszírozásától, a társadalmi szerveződések hagyományától, a vállalkozásfejlesztésre létrehozott intézményrendszertől, a bankrendszertöl, az oktatási rendszertöl, az érdekvédelmi szervezetek erejétöl, hogy csak a legfontosabbakat említsük.

Mivel a helyi gazdaságfejlesztésben részt vevök köre országonként változik, az általuk létrehozott helyi gazdaságfejlesztési szervezetek is különbözőek lehetnek. A hangsúly nem is az egyes közremüködökön van, hanem sokkal inkább az általuk létrehozott együttmüködéseken, illetve a résztvevök közötti horizontális és vertikális kapcsolatokon (Cameron et al. 2000).

Az együttmüködések terén azonban a térség országai még kevés tapasztalatot tudnak felmutatni, hiszen csak most tanulják a partnerségépítés fortélyait (Puljiz 2004; Espon 2006). Társadalmi jellemzö továbbá az alacsony részvételi hajlandóság is, amely a rendszerváltó országok állampolgárainak kiábrándultságával és a közösségi ügyektől való távolmaradásával hozható összefüggésbe (Ploštajner-Mendeš 2004).

\section{A helyi gazdaságfejlesztés finanszírozása}

A finanszirozás kérdése mindig kritikus része a helyi fejlesztések folyamatának (Syrett 1995; Puljiz 2004). A pénz jelenti ugyanis a legnagyobb problémát a legtöbb helyi önkormányzat és fejlesztési szervezet számára a helyi gazdaságfejlesztés során.

A fejlesztések ösztőnzöje, kezdeményezöje, befogadója általában a helyi önkormányzat vagy az általa létrehozott gazdaságfejlesztő szervezet, ezért a biztos önkormányzati anyagi háttér elengedhetetlen feltétele a helyi fejlesztések elindulásának. Fontos kérdés, hogy mekkora összeg felett rendelkeznek a helyi önkormányzatok, ahogyan az is, hogy mennyire kötött ezeknek a kereteknek a felhasználása, illetve hogyan kell biztosítania a helyi szintnek az önkormányzati kötelező feladatok finanszírozását (kijárással, hatékony gazdálkodással, saját erő hozzátételével), azaz mekkora és milyen kötöttségü forrás áll rendelkezésükre a helyi gazdaságfejlesztési 
beavatkozások kivitelezésére. A helyi önkormányzatok szabadon felhasználható forrásai és a saját bevételei a biztosítékok arra, hogy a helyi körülményekhez, feltételrendszerhez igazodó, a helyi igényeknek megfelelö, a helyi kapcsolati hálóra építő fejlesztések megvalósulhatnak. Ehhez persze jó esetben hozzákapcsolódnak a külső, kiegészító források is, pl. pályázati pénzek, magántöke, kockázati tőke.

A központi állami és a nemzetközi, pl. EU-s (cél)támogatások veszélye, hogy eltéríthetik a helyi fejlesztési irányokat, föként ha a tervezés nem elterjedt, vagy csak irányelvszerú tervezés folyik (az íróasztalfíokok számára készített tervekkel) a helyi önkormányzatoknál.

Nem mindegy az sem, hogy milyen vagyoni háttérrel rendelkeznek az önkormányzatok, hiszen egy-egy projekthez sokszor elegendö az önkormányzati vagyon fejlesztési célú hasznosítása (telekbiztosítás, épületátadás stb.) is.

Mivel ahány ország, annyiféle önkormányzati és önkormányzati finanszírozăsi rendszer van, az önkormányzatok helyi gazdaságfejlesztési pénzügyi szerepvállalása nemzetközi szinten alig vagy egyáltalán nem, Közép-Kelet-Európa vonatkozásában is csak korlátozottan összevethető. A továbbiakban éppen ezért az egyes országok finanszírozási gyakorlatára koncentrálunk.

Lengyelországban a helyi önkormányzatok helyi gazdaságfejlesztési szerepvállalásának legföbb akadálya a feladatellátáshoz nem igazodó finanszírozási háttér. Az önkormányzatok költségvetési nehézségei leginkább abból fakadnak, hogy az alacsony jövedelmü helyi lakosság minimális adóbevételekhez juttatja őket, $\mathrm{s}$ ez megnehezíti a hitelfelvételt is (Young-Kaczmarek 2000). A szabályozási környezet legvitatottabb részei: a túl komplikált adórendszer, a helyi adók helyben maradó részének központi meghatározása, illetve a helyi adók allakításának korlátozott lehetősége. Probléma továbbá, hogy a magántőke jellemzően távol marad a helyi kezdeményezésektől (Young-Kaczmarek 2000; Dziemianowicz-Herbst 2005).

Szlovákiában szintén a helyi gazdaságfejlesztési kezdeményezések pénzügyi hátterének elöteremtése a legföbb akadály. A helyi önkormányzatok állami támogatásoktól való erőteljes függése, illetve a szabad felhasználású források (helyiadó-, díjbevételek) rendszertelen és elenyésző volta miatt jórészt kihasználatlanul hagyják azt a törvény adta lehetőséget, hogy pénzügyi támogatást nyújtsanak helyi vállalkozások (közszolgáltatások, vállalkozásfejlesztés, foglalkoztatás területeken), illetve önkormányzati célszervezetek számára (Buček 2005).

Csehországban a helyi önkormányzatok saját hatáskörükben alakíthatják a helyi díj- és adóbevételük (vagyonadó) nagyságát, beruházásaik finanszírozására pedig hitelt is felvehetnek, ugyanakkor a bevételeik többségére nincs ráhatásuk, így korlátozott finanszírozási szabadsággal rendelkeznek (Jahoda et al. 2006).

Bulgáriában a helyi önkormányzatoknak minimális ráhatásuk van a saját bevételeikre. Míg a helyi önkormányzatoknak nincs adókivetési, adó-megállapítási joguk (vannak viszont helyben maradó adók), a helyi díjtételeket és a helyi szolgáltatások árát szabadon alakíthatják, bár ebben az esetben is korlátot képeznek a tradíciók (a szolgáltatások tradicionálisan alacsony ára) és az alacsony helyi jövedelmek. Mindez 
azt determinálja, hogy csak szúk lehetőségekkel rendelkeznek a helyi gazdaságfejlesztési beavatkozások terén (Damianova et al. 2005).

Lettországban és Litvániában a helyi adók teljes hiánya (központi szabályozása), Észtországban a helyiadó-bevételek elenyészỏ volta, illetve a Balti államokban jellemzö alacsony egyéb saját bevételi (saját gazdasági tevékenység, dijak, bírságok) arány megkérdőjelezi a helyi önkormányzatok tényleges helyi gazdaságfejlesztési mozgásterét (Trasberg 2006), ezért a helyi fejlesztéseket a külső (állami, uniós és egyéb nemzetközi) támogatások lényegében determinálják (Petkevicius-Linartas 2005).

Magyarországon szintén problémaként jelentkezik az önkormányzati szektor finanszírozási formája és a települési önkormányzatok elégtelen mértékủ saját forrása. Jellemzö továbbá az állami források iránti növekvő igény, a fokozódó hitelfelvétel (nincs elkülönítve a likviditási és a fejlesztési rész) és a kontrolálatlan vagyonfelélés (Viguári 2006).

Az önkormányzatok fejlesztési lehetőségeit behatároló saját források legmeghatározóbb eleme a helyi iparüzési adóból származó bevételi rész. Ráadásul a hozzá kötődỏ kedvezmények és mentességek a legáltalánosabban használt helyi gazdaságfejlesztési eszközzé váltak Magyarországon. Ugyanakkor az uniós csatlakozás következtében pont ezzel, a letelepülö vállalkozások vonzásának legelterjedtebb formájával kell felhagyniuk a helyi döntéshozóknak. Ezért 2008-tól gondoskodni kell egy új helyi adórendszer bevezetésérỏl, melyet az (értékalapú) vagyonadókra kellene alapozni (Vigvári 2006).

Összegezve, a közép-kelet-európai országok általános jellemzöje a helyi önkormányzatok kedvezötlen finanszírozási helyzete, amely a feladatoktól szabaduló központi kormányzati és a növekvő szerepvállalásra kényszerülö helyi önkormányzati magatartás eredőjeként, illetve a feladatvállaláshoz nem igazodó finanszírozás következményeként jön létre. A saját bevételek növelésére a legtöbb esetben nincs reális esély a lakosság általános jövedelmi helyzete és adóterheltsége miatt, de elöfordul, hogy a megfeleló jogosítvány is hiányzik.

A külsö támogatások deformáló hatása a közép-kelet-európai térség valamennyi országát érinti.

A vizsgált országok többségében a helyi önkormányzatok rendelkeznek olyan mértékủ saját vagyonnal, amely lehetôvé teszi számukra a vagyonalapú gazdaságfejlesztési eszközök használatát. Vannak persze olyan országok, ahol az állami vagyon átadása körül is felmerülnek nehézségek, pl. Románia, Bulgária.

A hitelfelvétel szintén megengedett a legtöbb helyen, de míg pl. Csehországban a fejlesztési célú hitelfelvételt külön kezelik, addig Magyarországon a fejlesztési célú és a likviditási hitel közös szabályozás alá esik. 


\section{Összegzés}

A tanulmány a kỏzép-kelet-európai országok helyi gazdaságfejlesztési gyakorlatát mutatta be. A lehetséges helyi gazdaságfejlesztési szereplők kőzül döntően a helyi önkormányzatokra koncentráltunk, mivel a nemzetközi gyakorlathoz igazodóan ők a biztos résztvevői a helyi kezdeményezéseknek, de foglalkoztunk a többi közremüködő mozgásterével is.

Megállapítottuk, hogy a Nyugat-Európában „divatos” partnerség-építési, együttmüködési gyakorlatnak a közép-kelet-európai országokban még komoly akadályai vannak, s általános jellemző az alacsony társadalmi részvételi hajlandóság is.

A helyi gazdaságfejlesztési eszközrendszer elemzése során kirajzolódott, hogy ugyancsak homogén eszközhasználat jellemzi a közép-kelet-európai országok helyi önkormányzatait. Az alkalmazott instrumentumok az infrastruktúrafejlesztési, a pénzủgyi, a vagyonhoz kötődő, a marketing és promóciós, illetve az információszolgáltatási és tanácsadási eszközcsoportokba sorolhatók. A legáltalánosabban használt eszközök a kinálatoldali stratégiák általános uralmáról tanúskodnak, vagyis az alapvető cél a befektetök vonzása, és csak másodlagos elem a humán tőke fejlesztése vagy a helyi KKV-k támogatása (Čapková 2005). A nemzetközi tapasztalatok alapján ez az arány a jövöben módosulni fog, mégpedig a keresetoldali politikák javára.

A helyi önkormányzatok gazdaságfejlesztési beavatkozásainak sikere leginkább a gazdaságfejlesztési források nagyságrendjétől és megoszlásától (külső/belső, közösségi/magán források) függ, ezért vizsgálatunkban külön figyelmet szenteltünk a finanszírozás kérdéskörének. Fontosnak tartjuk az önkormányzati saját források, ezen belül is a helyi adók szerepét. Kiemelt figyelmet érdemel továbbá a helyi önkormányzatok hitelszerzési lehetösége, illetve vagyoni héttere is.

\section{Irodalom}

Alexandrova, S. (2006) Strengthening Local Revenue Management is a Track for Introduction Fiscal Decentralisation: The Case of Bulgaria. - Šević, Ž. (ed.) Local Government Financial Capacity Building in Trunsition Countries: Selected Country Studies. NISPAcee. Bratislava. 231-246. o.

Bennett, R.J.-Krebs, G. (1991) Local Economic Development. Public-Private Parmership Initiation in Britain and Germany. Belhaven Press, London-New York.

Blakely, E.J.-Bradshaw, T.K. (2002) Planning Local Economic Development. Theory and Practice. London, Sage Publications Ltd.

Buček, J. (2005) The Role of Local Government in Local Economic Development. Slovakia. - Cápkova, S. (ed.) Local Government and Economic Development. Open Society Institute, Budapest. 107-133. o.

Cameron, G.-Danson, M.-Halkier, H. (2000) Institutional Change, Governance and Regional Development: Problems and Perspectives. - Danson, M. el al. (eds.) Governance, Institutional Change and Regional Development. Hampshire, Ashgate, Aldershot. 266-275. o.

Čapková, S. (2005) Local Government and Economic Development. - Čapková. S. (ed.) Local Government and Economic Development. Open Society Institute, Budapest. 1-19. o.

Chandler, M. (2006) Revenue Raising and Accountabilily of Local Governments in Lithuania. - Šević, Ž. (ed.) Local Government Financial Capacity Building in Transition Countries: Selected Country Studies. NISPAcee, Bratislava. 27-42. 0. 
Damianova, A-Tzvetkovska, M.-Ivanov, S. (2005) The Role of Local Government is Local Economic Development. Bulgaria. - Capková, S. (ed.) Local Government and Economic Development. Open Society Institute, Budapest. 21-46. o.

Dziemianowicz, W.-Herbst, M. (2005) Territorial Self-Government and Local Economic Development. Poland. - Čapkova, S. (ed.) Local Government and Economic Development. Open Society Institute, Budapest. 65-85. 0.

Espon (2006) Espon 2.3.2.: Governance of territorial and urban policies from EU to local level. 2006. május -http:/www.espon.eu/mmp/online/website/content/projects/243/374/file_2186/draft_fr-2.3.2full.pdf -2006.10 .18 .

Faragó L. (1990) A helyi gazdaságfejlesztés el mélete. - Gazdasági Fórum. 2. 44-55. o.

Illés I. (2002) Közép-és Délkelet-Európa az ezredfordulón. Budapest-Pécs, Dialóg Campus Kiadó.

Jahoda, R.-Pekova, J.-Selesovsky, J. (2006) Building Fiscal Capacities in the Czech Republic. - Šević, Ž. (ed.) Local Government Financial Capacity Building in Transition Countries: Selected Country Studies. NISPAcee, Bratislava. 43-61. o.

Józsa Z. (2006) Önkormányzati szervezet, funkció, modernizáció. Dialóg Campus Kiadó, Budapest-Pécs. Kudrycka, B. (2004) Problems and Prospects of Preventing Conflict of Interest in Local Governments in the CEE Countries. Summary Report. - Kudrycka, B. (ed.) Combating Conflict of Interest in Local Governments in the CEE Countries. Open Society Institute, Budapest. 1-47. 0.

KSH (2006) Területi atlasz - Közigazgatási beosztás. - http://portal.ksh.hu/portal/page?_pageid=37,411629 \&_dad=portal\&_schema=PORTAL-2006.11.01.

Mezei (2004) Önkormányzati gazdaságfejlesztési gyakorlat a hazai településeken. - Pálné Kovács 1. (szerk.) Versenyképesség és igazgatás. MTA RKK, Pécs. 181-265. o.

Pálné Kovács I. (1999) Regionális politika és közigazgatás. Dialóg Campus Kiadó, Budapest-Pécs.

Pálné Kovács I. (2003) A területfejlesztés irányínása. PTE KTK Regionális Politika és Gazdaságtan Doktori Iskola Habilitációs Elöadások sorozata. PTE KTK, Pécs.

Pálné Kovács I. (2004) A regionális gazdaságfejlesztés irányítási összefưggései. - Pálné Kovács I. (szerk.) Versenyképesség és igazgatás. MTA RKK, Pécs. 11-31. o.

Petkevicius, A.-Linartas, R. (2005) The Role of Local Government in Local Economic Development. Lithuania. - Capkova, S. (ed.) Local Government and Economic Development. Open Society Institute, Budapest. 47-64. o.

Pilat, J. (2004) Waiting for a Conflict of Interest-Constitutional Law in Slovakia. - Kudrycka, B. (ed.) Combating Conflict of Interest in Local Govemments in the CEE Countries. Open Society Institute, Budapest. 285-326. o.

Ploštajner, Z.-Mendeš I. (2004) Citizens Participation. - How to Improve Development on Local Level? Handbook with Best Practice Examples from South-East Europe. Friedrich Ebert Stiftung. Zagreb. 97-113. o.

Pukis, M. (2004) The Progress of Regulation of Conflict of Interest in Local Government in Latvia. Kudrycka, B. (ed.) Combating Conflict of Interest in Local Governnents in the CEE Counuries. Open Society Institute, Budapest. 107-144. o.

Puljiz, J. (2004) Economic Development. - How to Improve Development on Local Level? Handbook with Best Practice Examples from South-East Europe. Friedrich Ebert Stiftung, Zagreb. 9-24. o.

Rechnitzer J. (szerk.) (2006) Magyarország rzerepvállalási leletóségei a kelet-, közép- és délkeleteurópapi terilletfejlesziési egyïtmüködésekben. Országtonulmányok. Az MTA RKK NYUTI Közleményei. 173 B. Kézirat. MTA RKK NYUTI, Györ.

Roussinova, P. (2004) The Bulgarian Experience with Building a Framework for the Prevention of Conflict of Interest Situation in Local Governments. - Kudrycka, B. (ed.) Combating Conflict of Interest in Local Governments in the CEE Countries. Open Society Institute, Budapest. 49-105. o.

Slovenia (2006) Slovenia in Brief. - http://www.uvi.gov.si/eng/slovenia/in-brief/state/ - 2006.10.27.

Somlyódyné Pfeil E. (2004) A gazdaságfejlesztés megjelenési formái a terujetfejlesztési régiók szintjén. - Pálné Kovács I. (szerk.) Versenyképesség és igazgatás. MTA RKK, Pécs. 141-160. o.

Swianiewicz, P. (2006) Local Taxes in Poland - A Base for Local Accountability? - Šević, Ž. (ed.) Local Government Financial Capacity Building in Transition Countries: Selected Country Studies. NISPAcee, Bratislava. 180-201. o.

Syrett, S. (1995) Local Development: Restructuring, Locality and Economic Initiative in Portugal. Avebury, Ashgate Publishing Company.

Syrett, S. (1997) The Politics of Partnership. The Role of Partners in Local Economic Development in Portugal. - European Urban and Regional Studies. 2. 99-114. o. 
Trasberg, V. (2006) Intergovernmental Fiscal Relations in the Baltic Municipalities. - Šević, Ž. (ed.) Local Government Financial Capacity Building in Transition Countries: Selected Country Studies. NISPAcee, Bratislava. 202-213. o.

Vigvári A. (2006) A decentralizáció és önkormányzati pénzügyi rendszer. - Vigvári A. (szerk.) Decentralizáció, transzparencia, elszámoltathatóság. Magyar Közigazgatási Intézet. Budapest. 175-198. o.

Wong, C. (1996) What is local economic development? A conceptual overview. - Occasional Paper. 49. Department of Planning and Landscape, University of Manchester.

Young, C.-Kaczmarek, S. (2000) Local government, local economic development and quality of life in Poland. - GeoJoumal. 2-3. 225-234. o. 